\title{
DZIAŁALNOŚĆ MUZYCZNA LEONA KUBICY NA ŚLĄSKU OPOLSKIM
}

\begin{abstract}
WSTĘP
Kultura muzyczna Śląska, jak zapewne żadnego innego regionu w Polsce, doczekała się bardzo wielu poświęconych jej monografii. Ciągle jednak pozostają w tej bogatej historiografii muzycznej białe plamy. W tę właśnie narrację doskonale wpisuje się Leon Kubica, dyrygent i kompozytor działający na terenie Śląska Opolskiego w I poł. XX w. Pozostawił on po sobie znaczącą spuściznę, która wskutek rozproszenia zbiorów oraz zniszczenia ich części pozostawała dotychczas poza zainteresowaniem badaczy. Dzięki podjętym badaniom archiwalnym udało się ustalić szereg nowych faktów dotyczących działalności Leona Kubicy w środowisku muzyków polskich na terenie Śląska Opolskiego.

Twórca ten nieznany jest dziś szerzej muzykologom, zaledwie w niektórych opracowaniach odnaleźć można lakoniczne wzmianki o jego życiu i twórczości, niektóre z nich są zaś nieprecyzyjne lub całkowicie błędne. Celem niniejszego opracowania jest przedstawienie najnowszych ustaleń dotyczących biografii Leona Kubicy, a także jego zaangażowania w środowisko muzyczne Śląska Opolskiego. Jako szczególnie cenny i popularny w epoce przykład jego twórczości w końcowej części niniejszego artykułu omówiona zostanie jego „Msza polska «Ojcze łaskawy»”.
\end{abstract}

Mgr ANDRZEJ EDWARd GodEK - doktorant Instytutu Muzykologii Uniwersytetu Jagiellońskiego w Krakowie; e-mail: andres.godek@gmail.com

ANDrZej Edward GodeK - PhD candidate, Institute of Musicology, Jagiellonian University in Kraków; e-mail address: andres.godek@gmail.com 


\section{LEON KUBICA \\ A POLSKA KULTURA MUZYCZNA ŚLĄSKA OPOLSKIEGO}

Leon Kubica urodził się 26 lipca 1903 r. w Czekanowie jako syn Jana i Franciszki z d. Smolik. Informacje o jego początkowych latach życia są nieliczne: po ukończeniu niemieckiej szkoły powszechnej w 1917 r. odbywał w latach 1917-1927 praktyki w biurze kopalni „Concordia” w Zabrzu w charakterze pomocnika księgowego', w $1921 \mathrm{r}$. wziął zaś udział w III Powstaniu Śląskim. Współorganizował polski Klub Sportowy „Piast” w Zabrzu, był również członkiem Towarzystwa Gimnastycznego „Sokół”.

Początkowe kształcenie muzyczne odbierał u Mateusza Głąba, organisty kościoła pw. św. Agnieszki w Zabrzu³, a następnie w latach 1925-1927 uczył się w prywatnym Konserwatorium Muzycznym Tomasza Cieplika w Bytomiu oraz w Konserwatorium Muzycznym w Poznaniu ${ }^{4}$. W czasie tym zaangażowany był czynnie w działalność Związku Powstańców Śląskich, a podczas zjazdu okręgowego w Rzuchowie w 1927 r. wybrany został na członka komisji rewizyjnej tegoż związku W 1927 r. wyjechał do Ratyzbony, gdzie od 15 października t.r. do 15 lipca 1928 r. uczestniczył w rocznym kursie w Szkole Muzyki Kościelnej ${ }^{6}$. Mimo iż zachowało się świadectwo jego ukończenia, próżno szukać Kubicy w spisie uczniów tejże szkoły, gdyż ten za rzeczony okres pozostaje niepełny. Katalog absolwentów klasy z 1928 r. wylicza zaledwie trzech uczniów: Johannesa Pöcha, Johanna Schindlera oraz Norberta Stannka z Wrocławia ${ }^{7}$. Jeśli dać wiarę nocie prasowej opublikowanej z okazji ukończenia przez Kubicę kursu, jego świadectwo miałoby być drugim najlepszym spośród łącznej liczby 20 słuchaczy kursu, z których zaledwie 9 zdało końcowy egzamin ${ }^{8}$. Z zachowanego świadectwa wiadomo, że w zakresie gry na or-

${ }^{1}$ R. HANKe, Stownik polskiego śpiewactwa Górnego Ślaska, Katowice 2001, s. 163; P. ŚwIERC, Kubica Leon, „Śpiewak Śląski” 1987, nr 3 (268), s. 25-26.

${ }^{2}$ R. HANKe, Stownik polskiego śpiewactwa, s. 163.

${ }^{3}$ Tamże.

${ }^{4}$ Świetny egzamin młodego muzyka śląskiego, „Katolik Codzienny” 1928, nr 170, s. 3; Świetny egzamin młodego muzyka śląskiego, „Nowiny Codzienne” 1928, nr 171, s. 3. Dokładny okres nauki w Konserwatorium Muzycznym w Poznaniu pozostaje nieznany, gdyż dokumentacja tej uczelni została zniszczona w czasie II wojny światowej. W opublikowanym spisie absolwentów Leon Kubica nie został wyliczony. Absolwenci uczelni w: Akademia Muzyczna w Poznaniu 1920-1995, red. J. Tatarska, Poznań 1995, s. 225-226.

${ }^{5}$ Związek Powstańców Śląskich, „Polska Zachodnia” 1927, nr 57, s. 8.

${ }^{6}$ Zbiory Rodziny Leona Kubicy (dalej: ZRLK), b. sygn., Zeugnis von Kubitza Leon, passim.

${ }^{7}$ J. LibBert, Die Lehrer und Schüler der Kirchenmusikschule Regensburg von 1874 bis 1974, w: Gloria Deo. Pax hominibus. Festschrift zum 100 jährigen Bestehen der Kirchenmusikschule Regensburg, red. F. Fleckenstein, Regensburg 1974, s. 405.

${ }^{8}$ Świetny egzamin młodego muzyka śląskiego, s. 3. 
ganach oraz nauki harmonii i instrumentacji Kubica kształcił się u Josepha Rennera, śpiewu u Karla Weinmanna, kontrapunktu i form muzycznych u Petera Griesbachera, a łaciny u ks. Adolfa Veitha ${ }^{9}$.

Pierwsze wzmianki o zaangażowaniu Kubicy w działalność muzyczną polskiego środowiska na Śląsku Opolskim pochodzą z 1927 r. Dnia 24 lipca w czasie „Święta pieśni” w Groszowicach odbył się zjazd chórów, w którym wzięli udział m.in. polski konsul z Bytomia Michał Świrski, dyrygent chóru „Chopin” z Leszna Roman Lubierski, a także Leon Kubica z Zaborza. Zbiorowy Chór Górnośląski wykonał wówczas „Modlitwę” Stanisława Moniuszki, „Marzenie” Chopina oraz składającą się z dwóch zwrotek oraz finału pieśń „Śląska Ojczyzno” Kubicy. Jak donosiła ówczesna prasa, „finał tej pieśni został w Groszowicach po raz pierwszy wykonany”10, premiera początkowych zwrotek miała zaś miejsce niespełna miesiąc wcześniej. Przygotowania do wykonania utworu rozpoczął Jan Witt prawdopodobnie również w 1927 r., gdyż wtedy zebrał 70 członków chórów z Zabrza, Zaborza, Raciborza, Opola, Groszowiec, Wójtowej Wsi, Popiełowa, Siołkowic, Czyszek oraz Oleśna w jeden Zbiorowy Chór Górnośląski. Witt składając sprawozdanie z działalności tych połączonych zespołów napisał, iż „pieśń «Śląska ojczyzno» niesie przez swój tekst i jako kompozycja naszego p. Kubicy czysto-śląski charakter" ${ }^{\prime 1}$.

W latach 1923-1926 podjęto szczególne starania o rozwój ruchu śpiewackiego na terenie Śląska Opolskiego. Rezultatem tych zabiegów było powołanie wielu nowych zespołów muzycznych. W 1925 r. założony został „Chór kościelny” w Zaborzu przy parafii pw. św. Franciszka, którego pierwszym dyrygentem został Jan Witt $^{12}$. W sprawozdaniu z działalności Związku Kół Śpiewackich za 1927 r. zespół ten określony został jako „najsilniejsze i najruchliwsze towarzystwo” odbywając w okresie sprawozdawczym 48 prób oraz dając 11 występów ${ }^{13}$, licząc przy tym aż 106 członków czynnych ${ }^{14} .13$ października 1927 r. odbył się walny zjazd delegatów Związku, w wyniku którego dokonano podziału Śląska Opolskiego na cztery okręgi.

${ }^{9}$ ZRLK, A. Jonecko, Leon Kubica, s. 2, mps; J. LibBert, Die Lehrer, s. 380-387.

${ }^{10}$ Święto pieśni w Groszowicach, „Nowiny Codzienne” 1927, nr 170, s. 3.

${ }^{11}$ Archiwum Akt Nowych (dalej: AAN), Konsulat Generalny RP w Opolu (2/482), sygn. 98, Sprawozdanie z działalności wedle Chóru Górnośląskiego od jego założenia aż do pierwszego występu na uroczystości Związku Młodzieży, mps, passim. Fotografia Chóru Górnośląskiego oraz zdjęcie Leona Kubicy zostały zamieszczone w publikacji: Towarzystwa śpiewacze na Śląsku Opolskim, w: Obrazki z życia ludu polskiego na Śląsku Opolskim, Bytom 1927, s. 6.

${ }^{12}$ AAN, Konsulat Generalny RP w Opolu (2/482), sygn. 98, Sprawozdanie z działalności Związku Kół Śpiewackich za rok 1927, mps, passim.

${ }^{13}$ Tamże.

${ }^{14}$ AAN, Konsulat Generalny RP w Opolu (2/482), sygn. 98, Nota o stanie ruchu śpiewaczego na Śląsku Opolskim, mps, passim. 
Zabrze oraz Zaborze znalazły się w okręgu zabrsko-bytomsko-gliwickim ${ }^{15}$. Brak jest informacji kiedy dokładnie Kubica objął kierownictwo nad „Chórem kościelnym” z Zaborza, stało się to najprawdopodobniej około 1929 r., gdyż w roku poprzednim zespołem ciągle kierował Jan Witt ${ }^{16}$. Z pewnością w momencie przejęcia chóru przez Kubicę zespół prezentował już wysoki poziom wypracowany przez poprzedniego dyrygenta, o czym świadczą wyniki licznych konkursów, w których startował, m.in. w 1928 r. uzyskał 3 miejsce wśród chórów Śląska Opolskiego zdobywając 83 punkty, a przegrywając wyłącznie z chórami „Harmonia” z Wrocławia (91 punktów) oraz „Chopin” z Zabrza (87 punktów) ${ }^{17}$.

Poczynając od 1929 r. liczba wzmianek o działalności Leona Kubicy znacznie się zwiększa. Jako członek Związku Kół Śpiewaczych na Śląsku Opolskim dyrygował on jednocześnie kilkoma zespołami: „Chórem męskim” oraz „Chórem kościelnym św. Andrzeja” z Zabrza ${ }^{18}$, Towarzystwem Śpiewu Kongregacji Mariańskiej z Sośnicy (zwanym również „Chórem kościelnym” ${ }^{19}$ ) „Gwiazda” z Mikulczyc ${ }^{21}$ oraz „Chórem kościelnym” z Piaskowca ${ }^{22}$. Podczas „popisu" w czasie IV Zjazdu Związku, chóry dyrygowane przez Kubicę zdobyły dwa pierwsze miejsca: wygrał „Chór kościelny św. Franciszka” z wynikiem 89 punktów, drugie miejsce zajął zaś „Chór kościelny św. Andrzeja” z wynikiem 67 punktów ${ }^{23}$.

Środowisko zawodowych muzyków, zaangażowanych w prace Związku, było niewielkie. Fakt ten w znacznym stopniu przyczynił się do sytuacji, w której każdy z dyrygentów prowadził jednocześnie kilka zespołów. Ze sprawozdania za $1932 \mathrm{r}$. wynika co prawda, że łączna liczba dyrygentów wynosiła 14, z tego jednak aż 10 miało charakter pomocniczych. Na grono to składało się 3 organistów, 2 muzy-

${ }^{15}$ Walny zjazd delegatów Związku Kót Śpiewackich, „Katolik Codzienny” 1927, nr 262, s. 3.

${ }^{16}$ Sprawozdanie z naszego gliwickiego zjazdu śpiewaczego, „Nowiny Codzienne” 1928, nr 106 , s. 2.

${ }^{17}$ Tamże.

${ }^{18}$ AAN, Konsulat Generalny RP w Opolu (2/482), sygn. 98, Program IV Zjazdu Związku Kół Śpiewackich na Śląsku Opolskim w 1930 r.

${ }^{19}$ AAN, Konsulat Generalny RP w Opolu (2/482), sygn. 98, Program jubileuszu 25-lecia Związku Kół Śpiewackich.

${ }^{20}$ AAN, Konsulat Generalny RP w Opolu (2/482), sygn. 98, Program Piątego Zjazdu Związku Kół Śpiewackich na Śląsku Opolskim w 1931 r.

${ }^{21}$ AAN, Konsulat Generalny RP w Opolu (2/482), sygn. 98, Program jubileuszu 25-lecia Związku Kół Śpiewackich.

${ }^{22}$ Piękna manifestacja narodowa byt popisowy zjazd śpiewaczy Okręgu I w Gliwicach, „Nowiny Codzienne" 1936, nr 115, s. 7.

${ }^{23}$ Wyniki konkursowe IV. Zjazdu Śpiewaczego na Śląsku Opolskim, „Katolik Codzienny” 1930, nr 143, s. 2. 
ków, 6 nauczycieli, 2 urzędników i 1 robotnik $^{24}$. Aby poprawić tę sytuację, zorganizowane zostały kursy dyrygenckie, na które zapisało się 18 słuchaczy. W Opolu prowadzili je Jan Witt oraz Stefan Gawlik, w Gliwicach zaś Leon Kubica oraz Henryk Tondera ${ }^{25}$. W kolejnych latach zwiększono liczbę ośrodków, w których organizowano kurs, tak iż w Zabrzu i Bytomiu zajęcia prowadził Kubica, Witt zaś w Raciborzu oraz Opolu. Kurs w Bytomiu odznaczał się jednakże węższym programem, jako iż słuchacze byli dopiero „kandydatami na dyrygentów”26.

Obok dyrygentów poszczególnych zespołów, Związek posiadał również „dyrygenta związkowego" obieranego w drodze wyborów. Od początku omawianego tu okresu funkcję tę pełnił Jan Witt. W 1932 r. zgłoszono 3 kandydatów do tej funkcji. W wyniku głosowania Kubica oraz Witt uzyskali po 15 głosów, Tondera zaś $9^{27}$. Jak podaje protokół, „p. Kubica oświadczył, że urzędu [...] nie może przyjąć i nie przyjmie"28. Wobec zaistniałej sytuacji przeprowadzona została druga tura wyborów, w rezultacie której funkcję dyrygenta związkowego utrzymał Jan Witt ${ }^{29}$.

W 1930 r. „Chór kościelny św. Franciszka” świętował jubileusz pięciolecia działalności. W czasie Mszy św., odprawionej na tę okoliczność, zespół wykonał „Mszę G-dur” Franza Schuberta oraz dwie kompozycje Kubicy: „Weź w swą opiekę” na Offertorium oraz „Tantum ergo" na Ite Missa est ${ }^{30}$. Wybór mszy Schuberta na tę uroczystość wydaje się szczególnie ciekawy, skoro z okazji pięciolecia działalności zespołu Leon Kubica napisał własną „Mszę polską ”31. Stanowi ona jedną z przynajmniej trzech takich mszy przezeń skomponowanych. Oprócz nich, Kubica opracował na chór szereg pieśni zarówno kościelnych jak i świeckich. Dzieła te, poczynając od 1927 r., były chętnie i często wykonywane przez zespoły działające na Śląsku Opolskim. Dzięki zgromadzonym drukom ulotnym, sprawozdaniom z działalności poszczególnych chórów oraz prasie możliwe jest sporządzenie listy kompozycji Kubicy wykonanych na Śląsku Opolskim w latach 1927-1939 (zob. tabela 1.).

${ }^{24}$ AAN, Konsulat Generalny RP w Opolu (2/482), sygn. 98, Sprawozdanie z działalności Związku Kół Śpiewaczych na Śląsku Opolskim za 1932 r., mps.

${ }^{25}$ AAN, Konsulat Generalny RP w Opolu (2/482), sygn. 98, Protokół 6. Walnego Zebrania Delegatów Kół Śpiewaczych Śląska Opolskiego odbytego w Gliwicach dnia 28 lutego 1932 r., mps.

${ }^{26}$ AAN, Konsulat Generalny RP w Opolu (2/482), sygn. 98, Kurs dla dyrygentów, mps.

${ }^{27}$ AAN, Konsulat Generalny RP w Opolu (2/482), sygn. 98, Protokół 6. Walnego Zebrania Delegatów Kół Śpiewaczych Śląska Opolskiego odbytego w Gliwicach dnia 28 lutego 1932 r., mps.

${ }^{28}$ Tamże.

${ }^{29}$ Tamże.

${ }^{30}$ AAN, Konsulat Generalny RP w Opolu (2/482), sygn. 98, Program obchodów pięciolecia chóru św. Franciszka.

${ }^{31}$ Kompozycja ta nie jest tożsama z omawianą w dalszej części „Mszą polską «Ojcze łaskawy»”. ZRLK, b. sygn., Autograf „Mszy polskiej” Leona Kubicy, rps, passim. 
Tabela 1. Chronologiczny spis wykonań utworów Leona Kubicy do 1939 r.

\begin{tabular}{|c|c|c|c|}
\hline $\begin{array}{c}\text { Tytul } \\
\text { kompozycji }\end{array}$ & $\begin{array}{c}\text { Data } \\
\text { wykonania }\end{array}$ & Wykonawca & Okoliczność \\
\hline „Śląska & 12 VI 1927 r. & $\begin{array}{c}\text { „Zbiorowy } \\
\text { Chór Górnośląski" }\end{array}$ & $\begin{array}{l}\text { Wieczornica Związku } \\
\text { Stowarzyszeń Młodzieży } \\
\text { Polsko-Katolickiej } \\
\text { na Śląsku Opolskim } \\
\text { w Wójtowej Wsi }\end{array}$ \\
\hline $\begin{array}{l}\text { „Śląska } \\
\text { Ojczyzno”a }\end{array}$ & 24 VII $1927 \mathrm{r}$. & $\begin{array}{c}\text { „Zbiorowy Chór Górnośląski”, } \\
\text { dyr. J. Witt }\end{array}$ & $\begin{array}{l}\text { „Święto pieśni” } \\
\text { w Groszowicach }\end{array}$ \\
\hline $\begin{array}{l}\text { „I nie miej } \\
\text { do mnie żalu”b }\end{array}$ & 19 II 1928 r. & $\begin{array}{l}\text { Towarzystwo Śpiewu } \\
\text { „Chopin” z Zabrza, } \\
\text { dyr. H. Tondera }\end{array}$ & $\begin{array}{l}\text { Walne zebranie } \\
\text { i uroczystość Harcerstwa } \\
\text { Polskiego w Niemczech }\end{array}$ \\
\hline „Tantum ergo"c & 27 I 1929 r. & $\begin{array}{l}\text { Chór „Chopin” z Zabrza, } \\
\text { dyr. H. Tondera }\end{array}$ & $\begin{array}{l}\text { Msza św. z okazji I rocznicy } \\
\text { założenia tegoż chóru }\end{array}$ \\
\hline $\begin{array}{c}\text { „Pieśń } \\
\text { powitalna”d }\end{array}$ & 27 I 1929 r. & $\begin{array}{l}\text { Chór „Chopin” z Zabrza, } \\
\text { dyr. H. Tondera? }\end{array}$ & $\begin{array}{l}\text { Wieczór pieśni z okazji } \\
\text { I rocznicy założenia tegoż } \\
\text { chóru }\end{array}$ \\
\hline $\begin{array}{l}\text { "Gdybym } \\
\text { ja była"e }\end{array}$ & 27 I 1929 r. & Sopranistka, p. Czyjarkówna & $\begin{array}{l}\text { Wieczór pieśni z okazji } \\
\text { I rocznicy założenia } \\
\text { tegoż chóru }\end{array}$ \\
\hline $\begin{array}{l}\text { „Zwiędłe } \\
\text { zdeptane róże"f }\end{array}$ & 27 I 1929 r. & Sopranistka, p. Czyjarkówna & $\begin{array}{l}\text { Wieczór pieśni z okazji } \\
\text { I rocznicy założenia } \\
\text { tegoż chóru }\end{array}$ \\
\hline $\begin{array}{l}\text { „Alleluja, żyw } \\
\text { już jest śmierci } \\
\text { Zwyciężyciel”" }\end{array}$ & 14 IV 1929 r. & $\begin{array}{c}\text { „Chór kościelny } \\
\text { św. Franciszka” z Zaborza, } \\
\text { dyr. J. Witt }\end{array}$ & $\begin{array}{l}\text { Pierwsza Komunia Święta } \\
\text { w kościele parafialnym } \\
\text { pw. św. Franciszka w Zaborzu }\end{array}$ \\
\hline $\begin{array}{l}\text { „Jezu Jezu do } \\
\text { mnie przyjdź”h }\end{array}$ & 14 IV 1929 r. & $\begin{array}{c}\text { „Chór kościelny } \\
\text { św. Franciszka” z Zaborza, } \\
\text { dyr. J. Witt }\end{array}$ & $\begin{array}{l}\text { Pierwsza Komunia Święta } \\
\text { w kościele parafialnym } \\
\text { pw. św. Franciszka w Zaborzu }\end{array}$ \\
\hline „Tantum ergo",i & 14 IV 1929 r. & $\begin{array}{c}\text { „Chór kościelny } \\
\text { św. Franciszka” z Zaborza, } \\
\text { dyr. J. Witt }\end{array}$ & $\begin{array}{l}\text { Pierwsza Komunia Święta } \\
\text { w kościele parafialnym } \\
\text { pw. św. Franciszka w Zaborzu }\end{array}$ \\
\hline $\begin{array}{l}\text { "Pojedziemy } \\
\text { na gon"; }\end{array}$ & 19 V 1929 r. & $\begin{array}{l}\text { „Zbiorowy Chór } \\
\text { Górnośląski”? }\end{array}$ & $\begin{array}{l}\text { Wszechsłowiański Zjazd } \\
\text { Śpiewaczy w Poznaniu }\end{array}$ \\
\hline $\begin{array}{l}\text { „Weź w swą } \\
\text { opiekę nasz } \\
\text { Kościół”k }\end{array}$ & 16 XI $1930 \mathrm{r}$. & $\begin{array}{l}\text { „Chór kościelny } \\
\text { św. Franciszka”, } \\
\text { dyr. L. Kubica }\end{array}$ & $\begin{array}{c}\text { Msza św. } \\
\text { z okazji pięciolecia } \\
\text { działalności tegoż chóru }\end{array}$ \\
\hline $\begin{array}{l}\text { „Dzięki Tobie } \\
\text { Boże"l }\end{array}$ & 16 XI 1930 r. & $\begin{array}{c}\text { „Chór kościelny } \\
\text { św. Franciszka”?, } \\
\text { dyr. L. Kubica? }\end{array}$ & $\begin{array}{l}\text { Wieczornica z okazji } \\
\text { pięciolecia tegoż chóru }\end{array}$ \\
\hline
\end{tabular}




\begin{tabular}{|c|c|c|c|}
\hline $\begin{array}{l}\text { „Dzisiaj siostry } \\
\text { powód mamy”m }\end{array}$ & $28 \mathrm{I} 1931 \mathrm{r}$. & „Garstka panienek” & $\begin{array}{c}\text { 60-lecie urodzin ks. Benka, } \\
\text { prezesa Związku Matek } \\
\text { i Kongregacji Panien } \\
\text { w Zaborzu }\end{array}$ \\
\hline $\begin{array}{l}\text { „O święta pieśni } \\
\text { gminna”n }\end{array}$ & 17 V $1931 \mathrm{r}$. & $\begin{array}{l}\text { Towarzystwo Śpiewu } \\
\text { „Lutnia” z Opola }\end{array}$ & $\begin{array}{l}\text { Uroczystość z okazji } \\
\text { rocznicy wskrzeszenia } \\
\text { tegoż chóru }\end{array}$ \\
\hline „Msza polska” & 23 VIII $1931 \mathrm{r}$. & $\begin{array}{c}\text { „Chór kościelny" } \\
\text { z towarzyszeniem orkiestry, } \\
\text { dyr. L. Kubica }\end{array}$ & $\begin{array}{c}\text { Uroczystość z okazji } \\
\text { I rocznicy wskrzeszenia } \\
\text { Towarzystwa Śpiewu „Lutnia” }\end{array}$ \\
\hline $\begin{array}{l}\text { "O święta pieśni } \\
\text { gminna”p }\end{array}$ & 6 IX 1931 r. & $\begin{array}{l}\text { Towarzystwo Śpiewu } \\
\text { „Lutnia” z Opola }\end{array}$ & $\begin{array}{l}\text { Dzień Pieśni Polskiej } \\
\text { w Wójtowej Wsi }\end{array}$ \\
\hline „Msza polska”q & 17 I 1932 r. & $\begin{array}{c}\text { Towarzystwo Śpiewu } \\
\text { „Jutrzenka” [z Wójtowej } \\
\text { Wsi?] z towarzyszeniem } \\
\text { orkiestry }\end{array}$ & $\begin{array}{l}\text { Msza św. w intencji } \\
\text { tegoż zespołu }\end{array}$ \\
\hline $\begin{array}{l}\text { „Msza } \\
\text { [polska?]”, }\end{array}$ & 3 IV 1932 r. & $\begin{array}{c}\text { Towarzystwo Śpiewu } \\
\text { „Lutnia” z Miechowic } \\
\text { z towarzyszeniem ,solowej } \\
\text { orkiestry”, dyr. H. Tondera }\end{array}$ & $\begin{array}{c}\text { Pierwsza Komunia Święta } \\
\text { w kościele parafialnym } \\
\text { w Miechowicach }\end{array}$ \\
\hline „Msza polska”s & $28 \mathrm{~V} 1933 \mathrm{r}$. & $\begin{array}{l}\text { Towarzystwo Śpiewu } \\
\text { „Halka” z Bytomia, } \\
\text { dyr. H. Tondera }\end{array}$ & $\begin{array}{l}\text { Nabożeństwo } \\
\text { w sali Gimnazjum } \\
\text { w Bytomiu }\end{array}$ \\
\hline $\begin{array}{l}\text { „O święta pieśni } \\
\text { gminna”t }\end{array}$ & 16 VII $1933 \mathrm{r}$. & $\begin{array}{l}\text { Tow. Śpiewu „Lutnia” } \\
\text { z Opola }\end{array}$ & $\begin{array}{l}\text { Wieczór Pieśni Polskiej } \\
\text { ku czci Fryderyka Chopina }\end{array}$ \\
\hline $\begin{array}{l}\text { „Weź w swą } \\
\text { opiekę nasz } \\
\text { Kościół } \\
\text { św[ięty]”u }\end{array}$ & 25 X 1934 r. & $\begin{array}{l}\text { "Chór kościelny } \\
\text { św. Franciszka” }\end{array}$ & $\begin{array}{l}\text { Msza św. z okazji } \\
\text { poświęcenia odnowionej } \\
\text { kapliczki w Zaborzu }\end{array}$ \\
\hline $\begin{array}{l}\text { „O Marja moja } \\
\text { radość” }\end{array}$ & 17 II 1935 r. & $\begin{array}{l}\text { "Chór Kongregacji } \\
\text { Marjańskiej” }\end{array}$ & $\begin{array}{l}\text { IV Okręgowy } \\
\text { Zjazd Popisowy }\end{array}$ \\
\hline $\begin{array}{l}\text { „Przyjechał } \\
\text { na zmowy”w }\end{array}$ & 17 II 1935 r. & $\begin{array}{l}\text { Towarzystwo Śpiewu } \\
\text { „Przyszłość” z Gogolina }\end{array}$ & $\begin{array}{l}\text { IV Okręgowy } \\
\text { Zjazd Popisowy }\end{array}$ \\
\hline „Msza polska”x & 28 IV 1935 r. & $\begin{array}{c}\text { Połączone chóry } \\
\text { z Miechowic i Bytomia } \\
\text { z towarzyszeniem orkiestry, } \\
\text { dyr. H. Tondera }\end{array}$ & $\begin{array}{c}\text { Pierwsza Komunia Święta } \\
\text { w kościele parafialnym } \\
\text { w Mikulczycach }\end{array}$ \\
\hline „Msza polska”y & 23 VI 1935 r. & $\begin{array}{l}\text { Towarzystwo Śpiewu } \\
\text { „Halka” z Bytomia } \\
\text { wraz z orkiestrą }\end{array}$ & $\begin{array}{l}\text { Nabożeństwo w czasie } \\
\text { Jubileuszu 25-lecia istnienia } \\
\text { Związku Kół Śpiewackich }\end{array}$ \\
\hline $\begin{array}{l}\text { „O święta pieśni } \\
\text { gminna”z }\end{array}$ & 23 VI 1935 r. & $\begin{array}{l}\text { „Zbiorowy Chór } \\
\text { Górnośląski”? }\end{array}$ & $\begin{array}{c}\text { Popisy konkursowe } \\
\text { w czasie Jubileuszu 25-lecia } \\
\text { Związku Kół Śpiewackich }\end{array}$ \\
\hline
\end{tabular}




\begin{tabular}{|c|c|c|c|}
\hline $\begin{array}{l}\text { „Msza } \\
\text { [polska?]”aa }\end{array}$ & 17 V 1936 r. & $\begin{array}{l}\text { Chóry z Gliwic i Bytomia, } \\
\text { dyr. Tondera }\end{array}$ & $\begin{array}{l}\text { Zjazd Okręgowy } \\
\text { w Gliwicach }\end{array}$ \\
\hline „Pożegnanie”ab & 19 IV 1936 r. & $\begin{array}{c}\text { „Chór Męski Kongregacji } \\
\text { Marjańskiej Młodzieńców } \\
\text { w Zaborzu” }\end{array}$ & Pożegnanie ks. Knosały \\
\hline $\begin{array}{l}\text { „Msza polska } \\
\text { G-dur”ac }\end{array}$ & V 1936 r. & $\begin{array}{c}\text { Towarzystwo Śpiewu } \\
\text { „Jutrzenka” z Gliwic } \\
\text { z towarzyszeniem orkiestry, } \\
\text { dyr. H. Tondera }\end{array}$ & $\begin{array}{c}\text { Msza św. w Wójtowej } \\
\text { Wsi w czasie Okręgowego } \\
\text { Zjazdu w Gliwicach }\end{array}$ \\
\hline $\begin{array}{l}\text { „Msza } \\
\text { [polska?]”ad }\end{array}$ & 29 VI 1936 r. & $\begin{array}{c}\text { Połączone chóry } \\
\text { ze Śląska Opolskiego, } \\
\text { dyr. J. Witt, } \\
\text { organy L. Kubica }\end{array}$ & $\begin{array}{c}\text { Nabożeństwo w kościele } \\
\text { pw. św. Krzyża w czasie } \\
\text { I Zlotu Śpiewaków Polskich } \\
\text { z Kraju i Zagranicy } \\
\text { w Warszawie }\end{array}$ \\
\hline $\begin{array}{c}\text { „Msza polska } \\
\text { «Ojcze } \\
\text { łaskawy»"ae }\end{array}$ & 11 X 1936 r. & $\begin{array}{l}\text { "Chór kościelny } \\
\text { św. Franciszka” z Zaborza }\end{array}$ & $\begin{array}{c}\text { [Msza św.?] w kościele } \\
\text { pw. św. Franciszka } \\
\text { w Zaborzu }\end{array}$ \\
\hline $\begin{array}{c}\text { „Msza polska } \\
\text { «Ojcze } \\
\text { łaskawy»" }\end{array}$ & 18 X 1936 r. & $\begin{array}{l}\text { „Chór kościelny } \\
\text { św. Franciszka” z Zaborza }\end{array}$ & $\begin{array}{c}\text { [Msza św.?] w kościele } \\
\text { pw. św. Jadwigi w Zaborzu }\end{array}$ \\
\hline $\begin{array}{c}\text { „Msza polska } \\
\text { «Ojcze } \\
\text { łaskawy»"ag }\end{array}$ & 8 XI 1936 r. & $\begin{array}{c}\text { Towarzystwo Śpiewu } \\
\text { „Chopin” z Zabrza } \\
\text { z towarzyszeniem orkiestry }\end{array}$ & $\begin{array}{l}\text { Msza św. z okazji 25-lecia } \\
\text { tegoż zespołu w kościele } \\
\text { pw. św. Andrzeja w Zabrzu }\end{array}$ \\
\hline $\begin{array}{c}\text { „Msza polska } \\
\text { «Ojcze } \\
\text { łaskawy»"ah }\end{array}$ & [X/XI] $1936 \mathrm{r}$. & $\begin{array}{l}\text { Towarzystwo Śpiewu } \\
\text { „Chopin” z Zabrza, } \\
\text { dyr. Tondera, } \\
\text { organy L. Kubica }\end{array}$ & $\begin{array}{l}\text { Msza św. z okazji } \\
\text { 25-lecia tegoż chóru }\end{array}$ \\
\hline $\begin{array}{l}\text { „Msza polska } \\
\text { «Ojcze } \\
\text { łaskawy»"ai }\end{array}$ & $\begin{array}{l}{[\mathrm{XI} / \mathrm{XII}]} \\
1936 \mathrm{r} .\end{array}$ & $\begin{array}{c}\text { „Chór kościelny” z Sośnicy } \\
\text { z towarzyszeniem orkiestry, } \\
\text { dyr. L. Kubica }\end{array}$ & $\begin{array}{c}\text { Msza św. z okazji } \\
\text { 25-lecia istnienia } \\
\text { Kongregacji Mariańskiej } \\
\text { Panien w Sośnicy }\end{array}$ \\
\hline $\begin{array}{l}\text { „Msza polska } \\
\text { «Z pokłonem»»"aj }\end{array}$ & 15 XI 1936 r. & $\begin{array}{c}\text { Połączone chóry: męski } \\
\text { „Hasło” oraz mieszany } \\
\text { „Harmonia” z Raciborza } \\
\text { z towarzyszeniem orkiestry, } \\
\text { dyr. J. Witt }\end{array}$ & $\begin{array}{l}\text { Nabożeństwo z okazji } \\
\text { pierwszej rocznicy } \\
\text { działalności Chóru } \\
\text { męskiego „Hasło” } \\
\text { z Raciborza }\end{array}$ \\
\hline „Msza polska”ak & 17 I 1937 r. & $\begin{array}{l}\text { Towarzystwo Śpiewackie } \\
\text { „Św. Cecylii” z Mikulczyc, } \\
\text { dyr. H. Tondera }\end{array}$ & $\begin{array}{c}\text { Nabożeństwo } \\
\text { w Mikulczycach }\end{array}$ \\
\hline $\begin{array}{l}\text { „Msza polska } \\
\text { G-dur”al }\end{array}$ & 6 VI 1937 r. & $\begin{array}{l}\text { "Chór miechowski wraz z } \\
\text { chórem bytomskim" } \\
\text { z towarzyszeniem orkiestry, } \\
\text { dyr. H. Tondera }\end{array}$ & $\begin{array}{l}\text { Msza św. z okazji } \\
\text { setnej rocznicy urodzin } \\
\text { ks. Norberta Bonczyka } \\
\text { w Miechowicach }\end{array}$ \\
\hline
\end{tabular}




\begin{tabular}{|c|c|c|c|}
\hline „Msza polska”am & 10 X 1937 r. & $\begin{array}{c}\text { „Chór Kościelny } \\
\text { św. Franciszka” z Zaborza } \\
\text { z towarzyszeniem orkiestry }\end{array}$ & $\begin{array}{c}\text { Suma odpustowa } \\
\text { w kościele } \\
\text { pw. św. Franciszka } \\
\text { w Zaborzu }\end{array}$ \\
\hline Kolędyan & 23 I $1938 \mathrm{r}$. & ?, dyr. L. Kubica & $\begin{array}{c}\text { Ogólny Zjazd Związku } \\
\text { Polskich Kół Śpiewaczych } \\
\text { Śląska Opolskiego } \\
\text { w Raciborzu }\end{array}$ \\
\hline
\end{tabular}

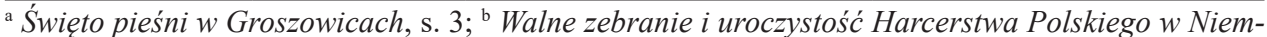
czech, „Katolik Codzienny” 1928, nr 44, s. 3; “ Uroczystość I. rocznicy Towarzystwa Śpiewu „Chopin” w Zabrzu, „Nowiny Codzienne” 1929, nr 49, s. 3; Śpiew polski, „Katolik Codzienny” 1929, nr 27, s. 3; “ Uroczystość I. rocznicy Towarzystwa Śpiewu ,Chopin ” w Zabrzu, „Nowiny Codzienne” 1929, nr 49, s. 3; " Uroczystość I. rocznicy Towarzystwa Śpiewu „, Chopin” w Zabrzu, „Nowiny Codzienne” 1929, nr 49, s. 3; f Uroczystość I. rocznicy Towarzystwa Ś 1929, nr 49, s. 3; " Listy ludowe. Zaborze, „Katolik Codzienny” 1929, nr 97, s. 3; ' Listy ludowe. Zaborze, „Katolik Codzienny” 1929, nr 97, s. 3; ' Listy ludowe. Zaborze, „Katolik Codzienny” 1929, nr 97, s. $3 ;{ }^{j}$ Autorstwo tego utworu nie zostało w programie oznaczone, przypisano je tu jako wątpliwe na podstawie publikacji: P. ŚwIERC, Leon Kubica, s. 26; Wszechsłowiański Zjazd Śpiewaczy 18-21 maja 1929 r. w Poznaniu, Poznań 1929, passim; ' AAN, Konsulat Generalny RP w Opolu (2/482), sygn. 98, Program obchodów pięciolecia chóru św. Franciszka; ${ }^{1}$ AAN, Konsulat Generalny RP w Opolu (2/482), sygn. 98, Program obchodów pięciolecia chóru św. Franciszka; ${ }^{\mathrm{m}}$ Wieczornica Zw. Matek i Kongregacji Panien, „Katolik Codzienny” 1931, nr 28, s. 3; " Towarzystwo Śpiewu „Lutnia” w Opolu, „Nowiny Codzienne” 1931, nr 108, s. 3; ' Z życia Kongregacji Marjańskiej, „Katolik Codzienny” 1931, nr 104,

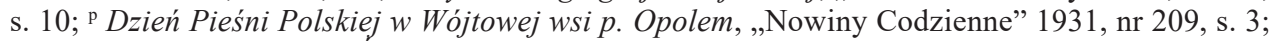

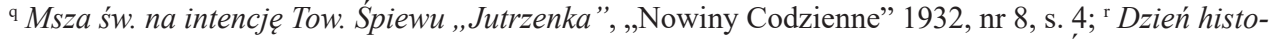
ryczny w Miechowicach, „Nowiny Codzienne” 1932, nr 80, s. 6; ' Z działalności Tow. Śpiewu „Halka” w Bytomiu, „Nowiny Codzienne” 1933, nr 117, s. 7; ' Z obchodu Chopinowskiego, „Nowiny Codzienne” 1933, nr 151, s. 3; Wieczór Pieśni Polskiej ku czci Fryderyka Chopina, „Nowiny Codzienne” 1933, nr 147, s. 4; "Odnowienie i poświęcenie kapliczki, „Nowiny Codzienne” 1934, nr 256, s. 3; " AAN, Konsulat Generalny RP w Opolu (2/482), sygn. 98, Program IV Okręgowego Zjazdu Popisowego; w Tamże; * Uroczystość I-ej Komunji świętej, „Nowiny Codzienne” 1935, nr 102, s. 3; y AAN, Konsulat Generalny RP w Opolu (2/482), sygn. 98, Program Jubileuszu 25-lecia istnienia Związku Kół Śpiewackich; Manifestacja Polskości 3000 śpiewaków, „Nowiny Codzienne” 1935, nr 143, s. 1; Wielki Zjazd Śpiewaczy w Bytomiu, „Nowiny Codzienne” 1935, nr 141, s. 3; ' AAN, Konsulat Generalny RP w Opolu (2/482), sygn. 98, Program Jubileuszu 25-lecia istnienia Związku Kół Śpiewackich; aa Zjazd Okręgowy w Gliwicach, „Przyjaciel pieśni” 1936, nr 3, s. 3; ab Pożegnanie dtugoletniego prezesa, „Przyjaciel pieśni” 1936, nr 3, s. 6; ac Piękna manifestacja narodowa byt popisowy zjazd śpiewaczy Okręgu I w Gliwicach, „Nowiny Codzienne” 1936, nr 115, s. 7; ad I Zlot Śpiewaków Polskich z Kraju i Zagranicy w Warszawie, „Przyjaciel pieśni” 1936, nr 7, s. 5; ae Teatr amatorski, „Nowiny Codzienne” 1936, nr 253, s. 3; af Teatr amatorski, „Nowiny Codzienne” 1936, nr 253, s. 3; ag Uroczystość śpiewacza w Zabrzu, „Nowiny Codzienne” 1936, nr 258, s. 4; ah Życie organizacyjne, „Przyjaciel pieśni” 1936, nr 8, s. 7; ai 25-lecie Kongregacji Mariańskiej, „Przyjaciel pieśni” 1936, nr 9, s. 14; aj Rocznica „Hasta”, „Przyjaciel pieśni” 1936, nr 9, s. 15; ak Życie organizacyjne, „Przyjaciel pieśni” 1937, nr 1, s. 6; Z życia towarzystw, „Nowiny Codzienne” 1937, nr 12, s. 3; al W setna rocznicę ks. Norberta Bonczyka, „Przyjaciel pieśni” 1937, nr 6, s. 2, 9; am Życie organizacyjne, „Przyjaciel pieśni” 1937, nr 10, s, 6; an Program Ogólnego Zjazdu Związku Polskich Kół Śpiewaczych Śląska Opolskiego w Raciborzu, „Przyjaciel pieśni” 1938, nr 1, s. 6. 
Powyższe wyliczenie nie obejmuje z pewnością wszystkich dzieł Leona Kubicy. Zaledwie nieliczne z nich ukazały się drukiem, jak np. pieśń „O święta pieśni gminna!"32. Szereg innych kompozycji Kubicy wyliczony został przez Piotra Świerca: „A ta śliczna Wisła na Śląsku wytrysła”, „I walcz na świt”, „Przed kim Osmana”, „Już wam więcej nie zadzwonią dzwony Kołomyji”, „Czerwony pas” oraz „Hej bracia opryszki" ${ }^{33}$. Autor ten wspomina również o istnieniu kwartetu smyczkowego, utworach organowych, a także muzyce do polskich sztuk teatralnych ${ }^{34}$. W świetle powyższego zestawienia można zauważyć, iż do najczęściej wykonywanych dzieł Kubicy należą jego msze polskie (18 wykonań), spośród których najczęściej odnotowano będącą przedmiotem niniejszych rozważań „Mszę polską «Ojcze łaskawy»” (5 wykonań). Uwagę zwraca również popularna pieśń „O święta pieśni gminna” (4 wykonania).

Niektóre z utworów Kubicy wykonywane były również po 1945 r., wśród nich m.in. „Msza polska” wykonana została przez Chór mieszany „Gwiazda” z Mikulczyc z okazji 25-lecia poświęcenia sztandaru tegoż zespołu w dn. 31 sierpnia $1947 \mathrm{r}^{35}$., czy też przez Chór „Chopin” z Zabrza pod dyrekcją Henryka Tondery w kościele pw. św. Andrzeja w Zabrzu w czasie Pierwszego Zjazdu Śpiewaków w 1947 r ${ }^{36}$.

Leon Kubica był również koncertującym muzykiem. O kilku wykonanych przezeń koncertach instrumentalnych wzmianki odnaleźć można w międzywojennej prasie. Do najważniejszych z nich należy występ w czasie „Wieczoru Pieśni i Słowa Polskiego" zorganizowanego 20 lipca 1930 r. w Opolu, kiedy Kubica wykonał na fisharmonii „Modlitwę” Stanisława Moniuszki oraz „Życzenie” Chopina „dając dowód wielkiej znajomości i opanowania tego instrumentu” ${ }^{37}$. Wykonaną przezeń na fortepianie w czasie „Obchodu Moniuszkowskiego” w Opolu w 1932 r. „Fantazję” z „Halki” opisano natomiast jako „niewątpliwe artystyczne ukoronowanie obchodu”38.

W związku z zaangażowaniem Kubicy po stronie polskiej, została mu przez Gestapo założona kartoteka ${ }^{39}$. W analogiczny sposób odnotowano również działalność innych muzyków zaangażowanych w ruch śpiewaczy na Śląsku Opolskim, m.in. Hen-

${ }^{32}$ Echa śląskie. Pieśni dla ludu polskiego na Ślasku Opolskim, cz. 1, Katowice 1935, s. 5-6.

${ }^{33}$ P. Świerc, Leon Kubica, s. 26.

${ }^{34}$ Tamże.

${ }^{35}$ Kronika Chóralna. Mikulczyce, „Śpiewak” 1947, nr 9, s. 13.

${ }^{36}$ Pierwszy zjazd śpiewaków okręgu zabrskiego, „Śpiewak” 1947, nr 7/8, s. 18.

${ }^{37}$ Wieczór Pieśni i Słowa Polskiego, „Katolik Codzienny” 1930, nr 169, s. 3.

${ }^{38}$ Wieczór Pieśni w Opolu, „Nowiny Codzienne” 1932, nr 47, s. 5.

${ }^{39}$ Archiwum Państwowe w Opolu (dalej: APO), Tajna Policja Państwowa w Opolu (45/56), sygn. 4475, Kubitza Leo ur. 26.07.1903 r. Hindenburg, passim. 
ryka Tondery ${ }^{40}$, Jana Witta ${ }^{41}$ czy też Stefana Gawlika ${ }^{42}$. Według informacji, zebranych przez Antoniego Jonecko, jeszcze przed wybuchem II wojny światowej Leon Kubica został aresztowany, a następnie przewieziony do obozu koncentracyjnego w Buchenwaldzie ${ }^{43}$. W czasie wojny został jednakże zwolniony i podjął pracę jako organista parafii pw. św. Mikołaja w Krapkowicach. Następnie został przymusowo wcielony do Wehrmachtu i wysłany na front wschodni ${ }^{44}$. Wtedy też dostał się do niewoli radzieckiej i umieszczony został w obozie jenieckim w Brześciu Litewskim, skąd przeniesiony został do obozu w Ligowie, gdzie ulec miał wypadkowi i zginąćc ${ }^{45}$.

\section{2. „MSZA POLSKA «OJCZE ŁASKAWY»”}

Mimo podjętych starań, nie udało się dotychczas odnaleźć autografu „Mszy polskiej «Ojcze łaskawy»" Leona Kubicy. Fakt ten jest o tyle dotkliwy dla prowadzonych nad jego twórczością badań, że jedyny dotychczas znany autorowi jej przekaz jest odpisem dzieła pochodzącym ze zbiorów rodziny kompozytora. Niestety zawiera on wiele błędów, brakuje w nim również całego Offertorium ${ }^{46}$. Karta tytułowa źródła informuje o oryginalnej obsadzie kompozycji:

Msza | Polska | na chór mieszany | Solo Tenor i Baryton z towarzyszeniem Organ lub orkiestry. | Obsada orkiestralna: | Kwintet smyczkowy | Klarnet I i II | Fagot I i II | Waltornia I i II | Tromba I i II | Puzon | Timpani ${ }^{47}$

W rzeczywistości jednak rękopis zawiera wyłącznie zapis partii chóru, głosów solowych oraz wyciąg organowy opatrzony sporadycznymi adnotacjami o realizacji poszczególnych odcinków przez inne instrumenty. Wydaje się, że wskutek

${ }^{40}$ APO, Tajna Policja Państwowa w Opolu (45/56), sygn. 7556, Tondera Heinrich ur. 11.07.1903 r. Hindenburg, passim.

${ }^{41}$ APO, Tajna Policja Państwowa w Opolu (45/56), sygn. 7897, Witt Johann ur. 7.02.1907 r. Zaborze, passim.

${ }^{42}$ APO, Tajna Policja Państwowa w Opolu (45/56), sygn. 1894, Gawlik Stefan, passim.

${ }^{43}$ A. Jonecko, Leon Kubica, s. 3.

${ }^{44}$ Tamże, s. 4.

${ }^{45}$ Antoni Jonecko powołuje się na relacje Antona Bartha, według której powóz konny wiozący Leona Kubicę najechać miał na minę. Według niego Kubica przeżył wybuch, jednak zmarł w czasie transportu do szpitala w Leningradzie. Tamże, s. 7-8.

${ }^{46} \mathrm{O}$ tym, że Offertorium wchodziło w skład mszy domniemywać możemy z faktu, iż w odpisie kompozycji zamieszczony został nagłówek „Offertorium” na dole strony verso. Na następnej karcie zapisane zostało jednakże Sanctus.

${ }^{47}$ ZRLK, b. sygn., Msza polska „Ojcze łaskawy”, k. 1r, rps. 
zredukowania partii orkiestry do rzeczonego wyciągu, akompaniament daleki pozostaje od oryginalnego brzmienia (o czym niżej).

Tekst części Kyrie, Credo, Sanctus oraz Agnus Dei wykorzystuje fragmenty „Mszy I Missyjną Zwaney” znanej m.in. ze „Śpiewnika kościelnego” ks. Marcina Mioduszewskiego ${ }^{48}$. Nie ustalono źródła tekstu dla części Gloria oraz Benedictus. Stanowią one jednakże dość wierną parafrazę tekstu łacińskiego, być może więc są dziełem samego kompozytora.

Większość części (Kyrie, Gloria, Credo, Agnus Dei) utrzymanych jest w tonacji głównej Ces-dur, Sanctus oraz Benedictus są zaś w tonacji B-dur. W całości kompozycji zastosowana została bogata chromatyka, co z pewnością stało się jednym z głównych powodów powstania licznych błędów w omawianym odpisie utworu. Ich wystąpienie jest jednak stosunkowo łatwe w korekcie, nie wykluczają one więc możliwości wykonania mszy z zachowanej partytury. W sposób wybiórczy i niekonsekwentny odnotowane zostały oznaczenia agogiczne i dynamiczne, domniemywać możemy zaledwie, że w autografie oznaczeń tych było więcej.

Wskazać można w tej mszy kilka głównych sposobów prowadzenia akompaniamentu. W całości kompozycji dominuje akordowy sposób jego realizacji, naprzemiennie stosowany z krótkimi figuracyjnymi motywami unisono (zob. przykład 1.). Wprowadzenie takich motywów w obrębie całej mszy zwykle stanowi wypełnienie pauz w partii chóru. Trudno mówić w tym przypadku o dialogu między nimi, brak jest bowiem w tych miejscach związku tematycznego między organami a partią chóru. Wydaje się więc, że figuracyjny charakter tych motywów wskazuje na ich quasi-ozdobnikowy charakter, w dalszej mierze zaś na próbę przydania partii instrumentalnej kształtu wirtuozowskiego (zob. przykład 2.). Drugim sposobem prowadzenia akompaniamentu, często wykorzystywanym w obrębie „Mszy polskiej”, jest wprowadzenie kilkutaktowych oktaw na pierwszym albo piątym stopniu. Zaledwie w nielicznych odcinkach oktawy takie wypełnione zostały innymi składnikami akordu (np. Kyrie, t. 37-39). Równie istotną rolę w kształtowaniu materiału muzycznego odgrywa dublowanie partii chóru przez organy, z czym związane jest szczególnie chętne prowadzenie równoległych oktaw w lewej ręce, których niższy dźwięk zapewne zapisany został z myślą o realizacji przez pedał. Partia pedału oznaczona została wyraźnie zaledwie w kilku taktach całej kompozycji. Wydaje się jednakże, że jej realizacja obejmować powinna wszystkie niskie długo wytrzymywane dźwięki zapisane w lewej ręce. $Z$ tego wynika jednak obraz mało ruchliwej partii, być może odpowiadającej oryginalnie kontrabasowi.

${ }^{48}$ M.M. MioduszewsKi, Śpiewnik kościelny czyli pieśni nabożne w kościele katolickim używane, Kraków 1838, s. 295. 
Przykład 1. Kyrie, t. 1-5.

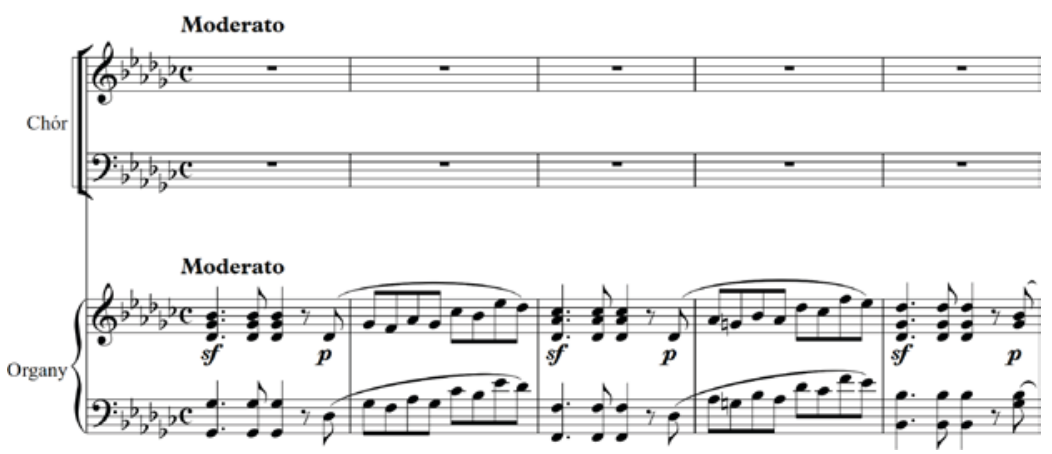

Przykład 2. Gloria, t. 44-46.

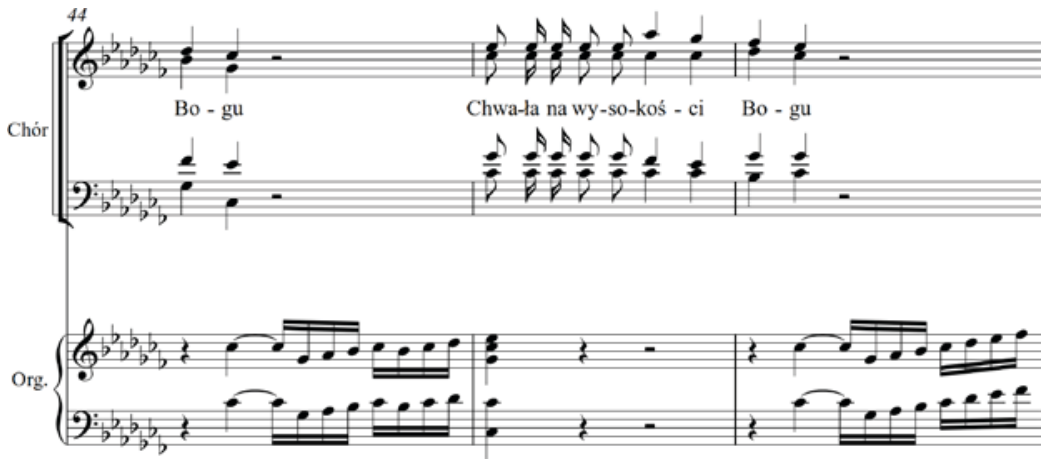

Partia chóru prowadzona jest z wyraźną dominacją faktury homofonicznej. Obsada przy tym ulega niekiedy redukcji. Szczególnym tego przykładem jest Benedictus, gdzie wprowadzony został duet głosów solowych sopran-alt (albo tenor-bas), między którymi realizowany jest dialog połączony z progresyjnym powtarzaniem tych samych motywów na kolejnych stopniach tonacji (zob. przykład 3). To progresyjne powtarzanie motywów wydaje się być jednym z najczęstszych zabiegów stosowanych we „Mszy polskiej” przez Leona Kubicę, czego przykłady odnaleźć można bez mała we wszystkich jej częściach. Bez wątpienia zabiegowi temu przypisać można funkcję retoryczną, szczególnie dostrzegalną w początkowym odcinku Sanctus, gdzie efekt ten jest wzmocniony przez narastanie dynamiki. Zauważyć jednocześnie należy, że w całym rękopisie informacje o realizacji dynamiki należą do bardzo sporadycznych, a ich nad wyraz tak precyzyjne odnotowanie w Sanctus nie znajduje odpowiednika w żadnej z innych części. 
Przykład 3. Benedictus, t. 24-26.

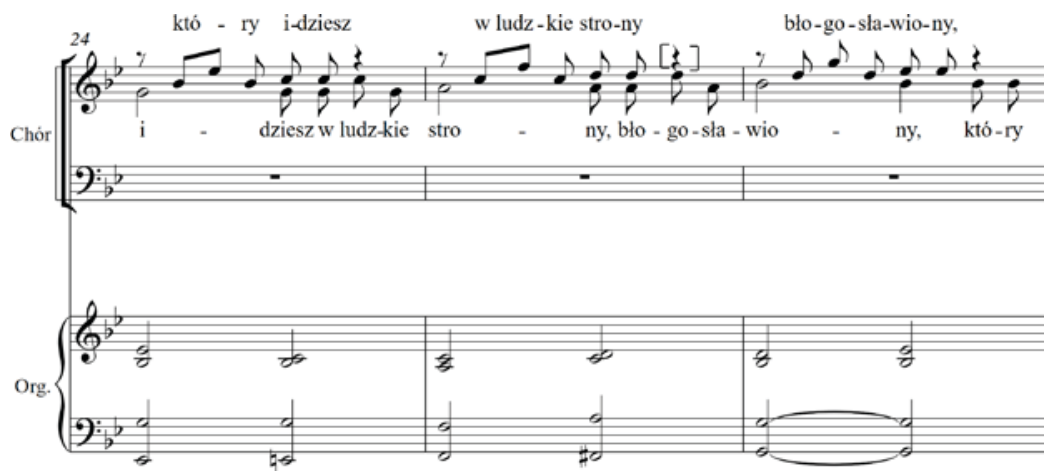

Odstępstwa od dominującej faktury nota contra notam należą do nielicznych, brak jest w kompozycji dłuższych odcinków polifonicznych. Większość przejawów polifonizacji faktury stanowią dwu lub trzydźwiękowe motywy wprowadzane na kształt imitacji najczęściej pomiędzy sopranem a tenorem. Dłuższe odcinki w imitacji, obejmujące frazy dwutaktowe, występują wyłącznie w części Credo (t. 11-13, 15-17). W każdej z tych sytuacji głosy powracają jednakże szybko do wyjściowej faktury homofonicznej (zob. przykład 4). Oprócz wyróżniania sopranu i tenoru, jako głosów prowadzących melodię, w licznych odcinkach głosy ulegają grupowaniu w pary sopran-alt, tenor-bas powtarzając w takim dwugłosie całe frazy (np. w Credo t. 25-30).

Przykład 4. Credo, t. 15-18.

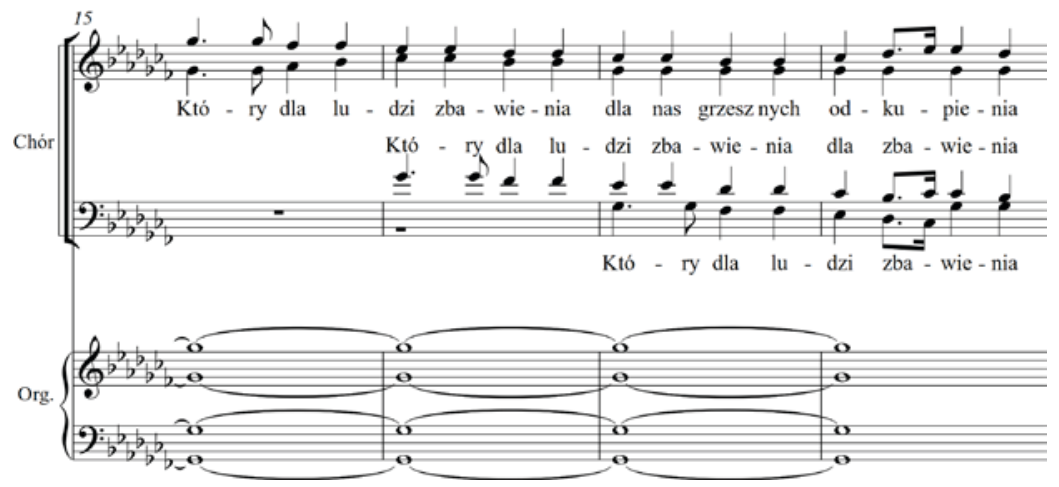

Mimo rozlicznych błędów w źródle oraz niespójności zapisu domniemywać możemy, że utwór w takim kształcie wykonywano. Spośród zebranych dotychczas informacji wynika, że był on jednym z najpopularniejszych dzieł Leona Kubicy 
(zob. Tabela 1.). Jednakże wobec nieodnalezienia dotychczas większości wzmiankowanych w toku niniejszych rozważań kompozycji, niemożliwe jest obecnie przedstawienie szczegółowej charakterystyki języka muzycznego przezeń stosowanego.

\section{ZAKOŃCZENIE}

Wśród zgromadzonych materiałów zachowało się zaledwie kilka opinii pozwalających na określenie jak sami Polacy postrzegali twórczość muzyczną Leona Kubicy. Wydaje się, że najważniejszym podkreślanym aspektem jest jego śląskie pochodzenie. Jeszcze przed wyjazdem do Ratyzbony oceniano jego dzieła jako „niosące [...] czysto-śląski charakter", co przejawiać się miało zarówno wspomnianym pochodzeniem twórcy, jak i zawartym w dziele tekście ${ }^{49}$. Pisząc o samych mszach podkreślano zaś ich „potężną melodię" ${ }^{{ }_{50}}$. Opinie te przenikały również do prasy innych środowisk polskich w III Rzeszy. W opublikowanym w 1938 r. w „Gazecie Olsztyńskiej” artykule, poświęconym polskiej muzyce w Niemczech, autor nazwał Leona Kubicę „głównym przedstawicielem indywidualnej twórczości muzyczno-religijnej” oraz twórcą „pełnego mistycznego nastroju mszy i pieśni kościelnych”51.

W omówionej w toku niniejszych rozważań „Mszy polskiej” niezwykle trudno wskazać jakiekolwiek elementy zawierające „czysto-śląski charakter”. Również rozlicznych trudności nastręcza kwestia „mistycznego nastroju”. Wydaje się wszakże, że rozpatrując to dzieło wyłącznie w kategoriach muzycznych nie wyróżnia się ono na tle twórczości religijnej swojej epoki. Jednocześnie ze względu na środowisko, w którym kompozycja ta powstała i była wykonywana, aspekt muzyczny zdaje się wcale nie wysuwać na pierwszy plan. Z licznych źródeł wyraźnie wynika, że Polacy mieszkający w Rzeszy postrzegali muzykę jako „bastion Wiary i Mowy Ojców" "52. Wydaje się więc, że właśnie ta perspektywa najlepiej thumaczy popularność dzieł Kubicy.

Zebrany w niniejszym artykule dotychczas materiał uzupełnia i porządkuje dotychczasowe wzmianki o działalności i twórczości muzycznej Leona Kubicy. Liczyć jednakże należy, że prowadzenie dalszych badań przyczyni się do odnalezienia kolejnych kompozycji Leona Kubicy.

${ }^{49}$ AAN, Konsulat Generalny RP w Opolu (2/482), sygn. 98, Sprawozdanie z działalności wedle Chóru Górnośląskiego od jego założenia aż do pierwszego występu na uroczystości Związku Młodzieży, mps.

${ }^{50}$ Manifestacja Polskości 3000 śpiewaków, s. 1.

${ }^{51}$ Muzyka i pieśń polska w Niemczech, „Gazeta Olsztyńska” 1938, nr 53, s. 6.

${ }^{52}$ Tamże. 


\section{BIBLIOGRAFIA}

\section{Źródła archiwalne}

Archiwum Akt Nowych w Warszawie

Zespół: Konsulat Generalny RP w Opolu (2/482): sygn. 98, Związki śpiewacze na Śląsku Opolskim.

Archiwum Państwowe w Opolu

Zespół: Tajna Policja Państwowa w Opolu (45/56):

sygn. 1894, Gawlik Stefan.

sygn. 4475, Kubitza Leo ur. 26.07.1903 r. Hindenburg.

sygn. 7556, Tondera Heinrich ur. 11.07.1903 r. Hindenburg.

sygn. 7897, Witt Johann ur. 7.02.1907 r. Zaborze.

Zbiory Rodziny Leona Kubicy:

b. sygn., Zeugnis von Kubitza Leon.

b. sygn., A. JONECKO, Leon Kubica, mps.

b. sygn., Autograf „Mszy polskiej” Leona Kubicy, rps.

b. sygn., Msza polska „Ojcze łaskawy”, rps.

\section{Źródla drukowane}

Echa śląskie. Pieśni dla ludu polskiego na Śląsku Opolskim, cz. 1, Katowice 1935.

„Gazeta Olsztyńska” 1938, nr 53.

„Katolik Codzienny” 1927, nr 262; 1928, nr 44, 170; 1929, nr 27, 97; 1930, nr 143, 169, 268; 1931, nr 28, 104.

Mıoduszewski M.M., Śpiewnik kościelny czyli pieśni nabożne w kościele katolickim używane, Kraków 1838.

„Nowiny Codzienne” 1927, nr 170; 1928, nr 106, 171; 1929, nr 49; 1931, nr 108, 209; 1932, nr 8, 47, 80; 1933, nr 117, 147, 151; 1934, nr 60, 256; 1935, nr 102, 141, 143; 1936, nr 84, 115, 253. „Polska Zachodnia” 1927, nr 57.

„Przyjaciel Pieśni” 1936, nr 3, 7, 8, 9; 1937, nr 1, 6, 10, 12; 1938, nr 1.

„Śpiewak” 1947, nr 7/8, 9.

„Śpiewak Śląski” 1987, nr 3 (268).

Wszechsłowiański Zjazd Śpiewaczy 18-21 maja 1929 r. w Poznaniu, Poznań 1929.

\section{Opracowania}

Akademia Muzyczna w Poznaniu 1920-1995, red. J. Tatarska, Poznań 1995.

Hanke R., Stownik polskiego śpiewactwa Górnego Ślaska, Katowice 2001.

LibBert J., Die Lehrer und Schüler der Kirchenmusikschule Regensburg von 1874 bis 1974, w: Gloria Deo. Pax hominibus. Festschrift zum 100 jährigen Bestehen der Kirchenmusikschule Regensburg, red. F. Fleckenstein, Regensburg 1974.

\section{DZIAŁALNOŚĆ MUZYCZNA LEONA KUBICY NA ŚLĄSKU OPOLSKIM}

\section{Streszczenie}

Niniejszy artykuł poświęcony jest życiu i muzycznej działalności Leona Kubicy, cenionego w okresie międzywojennym muzyka kościelnego ze Śląska Opolskiego. Był on uczniem Tomasza Cieplika, następnie zaś kontynuował naukę w Szkole Muzyki Religijnej w Ratyzbonie. W tym też czasie stał się znanym i cenionym kompozytorem. Jego dzieła wykonywane były przez liczne polskie 
chóry na terenie Śląska Opolskiego. Również sam Kubica był czynnym działaczem polskiego środowiska w Rzeszy Niemieckiej i dyrygował szeregiem zespołów. Zaangażowanie to przyczyniło się do jego początkowego uwięzienia w obozie koncentracyjnym w Buchenwaldzie, a następnie wysłania go na front wschodni, gdzie zginął.

Najnowsze badania oparte na prasie, spuściźnie kompozytora przechowywanej w zbiorach rodziny oraz na dokumentach z archiwów państwowych pozwoliły na przedstawienie nowych informacji do biografii Leona Kubicy, a także jego działalności muzycznej w środowisku polskim na terenie Śląska Opolskiego oraz listy wykonań jego dzieł do 1939 r. W ostatniej części rozważań przedstawiona została analiza Mszy polskiej, najbardziej znanej z jego kompozycji.

Słowa kluczowe: Leon Kubica; Śląsk Opolski; chóry kościelne; organiści; muzyka polska w Rzeszy Niemieckiej.

\section{THE MUSICAL ACTIVITY OF LEON KUBICA ON OPOLIAN SILESIA}

\section{Sum mary}

The article focuses on the life and musical activity of Leon Kubica, famous church musician of Opolian Silesia. Kubica was a pupil of Tomasz Cieplik, later he continued his musical education at the School Of Church Music at Regensburg. In this very time he became a very recognizable and valued composer. His works were performed by many polish choirs from Opolian Silesia. Kubica himself involved in the works of polish community in German Reich and became a conductor of a few ensembles. Such involvement resulted in imprisonment in death camp in Buchenwald, and later sending him on the eastern front, where he died.

Recent studies based on press, composer's legacy saved in his family's possession, and in national archives allowed to complement his biography, mentions about musical activity in polish society of Opolian Silesia and list of his works performances up to 1939. In the last part of this article the brief analysis of his Msza polska, his most famous composition.

Key words: Leon Kubica; Opolian Silesia; church choirs; organists; Polish music in German Reich. 